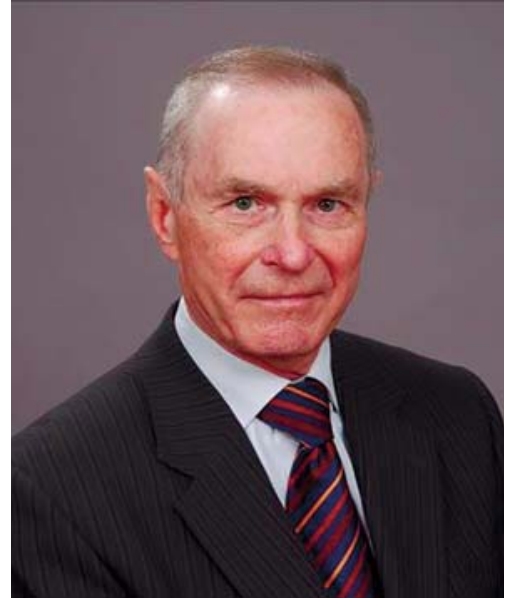

НАУМОВЕЦЬ

Антон Григорович академік НАН України, головний науковий співробітник відділу фізичної електроніки Інституту фізики НАН України

\section{ПОВЕРХНІ - ВСЮДИСУЩІ МЕЖІ ПОДІЛУ РІЗНИХ СЕРЕДОВИЩ}

\author{
Доповідь 3 нагоди вручення Золотої медалі \\ ім. В.I. Вернадського НАН України
}

Вельмишановний Анатолію Глібовичу!

Вельмишановні колеги!

Я глибоко вдячний усім вам за відзначення мене найвищою нагородою Національної академії наук України - Золотою медаллю імені Володимира Івановича Вернадського, видатного природознавця і першого президента Академіі. Для мене це надзвичайно велика честь, тим більше, що я отримую цю високу нагороду разом з видатним фізиком сучасності, президентом Австрійської академії наук професором Антоном Цайлінгером.

Я коротко розповім вам про науковий доробок, який разом зі своїми колегами я здобував протягом шести десятиліть в Інституті фізики НАН України. Йдеться про дослідження поверхонь. У природі вони є межами, які роз'єднують різні середовища, проте одночасно в науці вони міцно об'єднують інтереси всіх природознавців.

Явища на поверхнях складні, життєво важливі, вони широко використовуються на практиці, хоча нерідко бувають небезпечними. Куди б ми не поглянули, всюди бачимо поверхні. Проте люди часто висловлюються про них досить легковажно. Коли в побуті ми чуємо, що щось «лежить на поверхні», то це зазвичай означає, що воно є цілком зрозумілим, ясним, а вислів «поверхові знання» означає їх незадовільну оцінку. 3 іншого боку, один з творців квантової фізики Вольфганг Паулі дотепно сказав, що «поверхні вигадав диявол», маючи на увазі складність їх теоретичного опису.

Наведу лише кілька прикладів того, наскільки важливі поверхневі явища у природі і різних технологіях. Це, зокрема, так звані капілярні явища - змочування і розтікання, завдяки яким вода підіймається на висоту десятків і сотень метрів по стовбурах каліфорнійських секвой і коренями африканських акацій, які сягають глибини 30 м. I навпаки, листя лотоса приклад повного незмочування. 
Прикладом широкого застосування поверхневих явищ є каталіз. Наприклад, синтез такої важливої в хімічній промисловості речовини, як аміак, з водню і атмосферного азоту відбувається лише на поверхні каталізатора, на якій молекули $\mathrm{H}_{2}$ i $\mathrm{N}_{2}$ легко розкладаються $\mathrm{i}$ об'єднуються в молекули $\mathrm{NH}_{3}$.

Або процеси змащування і тертя, з якими ми щодня маємо справу. В них також ключову роль відіграють поверхні. Надзвичайно небезпечними є знайомі всім ожеледиці і обмерзання поверхні літаків. Також явища корозії на поверхнях можуть призводити до руйнування різних металевих конструкцій.

Нині ми спостерігаємо прагнення людства до мініатюризації всього, що можливо. Приклад у цьому подає електроніка. Дуже модним і широковживаним стало слово «нано», що грецькою означає «карлик». Ним позначають мільярдну частку чогось. Наприклад, довжина ланцюжка з чотирьох атомів заліза становить 1 нм. В описі нанометрових об'єктів уже не обійтися без квантової механіки. А роль поверхневих явищ колосально зростає при подрібненні речовини. Припустимо, ми маємо кубик з ребром 1 см, сумарна площа його шести граней

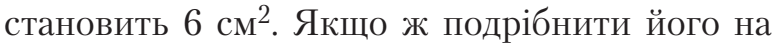
кубики розміром 1 нм, то простий розрахунок показує, що сумарна площа їх граней становитиме $6000 \mathrm{~m}^{2}$, що майже дорівнює площі футбольного поля нашого Олімпійського стадіону. По суті, особливий фізичний і хімічний стан атомів і молекул на поверхні зумовлений тим, що у них менше сусідів, ніж у атомів в об'ємі.

Переходячи до наших наукових результатів, я маю віддати данину нашим незабутнім попередникам. Це передусім відомий американський фізик і хімік, нобелівський лауреат Ірвінг Ленгмюр, а також наші видатні вчені в галузі вакуумної і плазмової електроніки Наум Давидович Моргуліс, який працював в Інституті фізики і Київському державному університеті ім. Т.Г. Шевченка, і Петро Григорович Борзяк, також співробітник Інституту фізики. Усі вони досліджували явища електронної емісії з твердих тіл, адже її інтенсивність надзвичайно сильно залежить від стану поверхні. Цей стан впливає на енергію, яка витрачається на емісію кожного електрона (iii називають роботою виходу). Джерела електронів (катоди) були і є неодмінною частиною всіх вакуумних електронних ламп, завдяки яким виникли радіотехніка і електроніка в усіх їх розмаїтих формах, а фотоелементи свого часу «озвучили» кіно.

Далі я буду використовувати деякі фахові терміни, тому нагадаю їх значення. Наш творчий колектив працював над різнобічним дослідженням адсорбційних явищ. Адсорбиія - це приєднання чужорідних атомів чи молекул до поверхні.

Атомна структура (атомний рельєф) різних граней одного кристала може дуже сильно різнитися - лише згадайте дивовижне розмаїття форм кристалів, наприклад сніжинок. Один щільно упакований на підкладці шар атомів чи молекул називають моношаром, йому приписують ступінь покриття, рівний одиниці. Діаметр атомів не перевищує 1 нм, тому всі атомні моношари є за своєю природою класичними двовимірними нанооб'єктами.

Нещільний моношар називають субмоношаром. Поки атомів-«чужинців» (ми скорочено називаємо їх адатомами) на поверхні небагато, їм енергетично вигідно сідати в ямках, які їм «пропонує» поверхня підкладки. Однак зі зростанням ступеня покриття починається конкуренція взаємодій адатомів з підкладкою і між самими адатомами (латеральна, тобто «бокова»). Відбувається те, що називають епітаксія (від грецьких слів «епі» - «на» і «таксіс» - «порядок, впорядковування»). Це, образно кажучи, нав’язування підкладкою структури плівці.

Уже давно було помічено, що не лише щільний моношар, а й інколи незначна його частка (1/10 чи навіть $1 / 100)$ можуть сильно змінювати властивості поверхні. Оскільки ми бажаємо одержати надійні експериментальні дані, ми повинні гарантувати чистоту умов експерименту, а це означає, що його потрібно виконувати у надвисокому вакуумі.

Потік молекул газу на одиницю поверхні за секунду залежно від тиску описується

ISSN 1027-3239. Visn. Nac. Acad. Nauk Ukr. 2021. (6) 
формулою:

$$
N=3,5 \cdot 10^{22} \cdot \frac{p_{\text {Torr }}}{\sqrt{M T}}\left(\mathrm{~cm}^{-2} \cdot \mathrm{c}^{-1}\right)
$$

(тиск тут наведено в одиницях Торричеллі так фізики називають 1 мм рт. ст. на честь Еванджеліста Торричеллі, відкривача атмосферного тиску).

Уявимо, що молекули газу при зіткненні 3 поверхнею відразу «прилипають» до неї (наприклад, для кисню на чистій поверхні металу це дійсно так). Тоді, як показує розрахунок, щільний моношар кисню при тиску $10^{-6}$ торр неконтрольовано утвориться приблизно за $1 \mathrm{c}$ і невпізнанно змінить те, що ви хотіли б дослідити. Тому для тривалого чистого експерименту потрібно досягти майже «космічного» вакууму $10^{-11}-10^{-12}$ торр.

В Інституті фізики НАН України ще в середині 1960-х років ми вирішили грунтовно дослідити так званий структурний фактор в адсорбції, тобто порівняти властивості адсорбційних систем, що являють собою поверхні різних граней одного кристала, покриті плівками однакового адсорбату. Ініціатором цієї роботи був Володимир Михайлович Гаврилюк, ветеран війни, який у 1954 р. захистив кандидатську дисертацію під керівництвом Н.Д. Моргуліса.

Масивних металічних монокристалів у нас тоді не було, і в ролі підкладки ми використали монокристалічне вольфрамове вістря (фактично голку) в польовому електронному мікроскопі-проєкторі, який ще перед війною винайшов у Німеччині Ервін Мюллер. У таких приладах вістря має дуже тонкий кінчик (радіус закруглення $\approx 10^{-5}$ см), завдяки чому біля нього легко створити дуже сильне електричне поле, в якому з вістря внаслідок квантового ефекту тунелювання емітуються електрони i проєктують на екран розподіл густини струму з різних граней вістря. Ця густина струму дуже сильно різниться для різних граней. Оболонку нашого мікроскопа в цільноскляному варіанті виготовив наш унікальний майстер-склодув Абрам Соломонович Карп, а саму конструкцію мікроскопа суттєво удосконалили ми з Олексієм Григоровичем Федорусом. Так, ми забезпеISSN 1027-3239. Вісн. НАН України, 2021, № 6 чили охолодження вістря рідким азотом і гелієм, а стінок приладу - рідким азотом; передбачили вимірювання роботи виходу електронів 3 окремих граней кристалика вольфраму, для чого в екрані було залишено маленький отвір для локальних вимірювань струму.

Важливо, що вимірювання здійснювалися залежно від абсолютної поверхневої концентрації адсорбату, яким у нас був цезій (це дуже цікавий «класичний» адсорбат, який почав досліджувати ще I. Ленгмюр). Ми знайшли, що ці залежності істотно різняться, а мінімуми на них досягаються при субмоношарових покриттях, у яких концентрації атомів цезію і вольфраму співвідносяться як невеликі цілі числа. Це «натякало» на можливість утворення на поверхні епітаксіальних плівок, структурно узгоджених з підкладкою. Одночасно ми побачили, що за кімнатної температури адатоми цезію на вольфрамі швидко рухаються (дифундують). Звідки випливало, що в таких умовах адсорбовані плівки можуть бути розупорядкованими (розплавленими).

Ми вирішили перевірити це, застосовуючи метод дифракції повільних електронів, який дозволяє досліджувати структуру поверхонь. Наші зарубіжні колеги мали цільнометалеві електронографи, які виробляли компанії у Великій Британії, Японії і Франції. У нас тоді таких не було, тому ми знову самотужки виготовили цільноскляний прилад. Зовні він виглядав не так ефектно, як фірмові, але натомість мав суттєву перевагу перед ними: давав можливість охолоджувати досліджуваний зразок рідким азотом або гелієм. За кімнатної температури ми бачили на екрані лише систему чітких світлих цяток - так званих дифракційних рефлексів, які відповідають структурі чистої підкладки. Коли ж ми вперше охолодили кристал, то з екрана наче завіса впала - ми побачили цілу серію картин, які давали інформацію про структуру плівки при різних ступенях покриття.

Отже, плівки дійсно впорядковуються при достатньому охолодженні. Розшифрування таких картин виявилося загалом не дуже складним і засвідчило формування багатьох 
двовимірних кристалів 3 досить великими відстанями між адсорбованими атомами. Що стосується дослідження самої поверхневої дифузії, то наш співробітник Юрій Степанович Ведула запропонував і реалізував оригінальний метод - сканувальну контактно-потенціальну мікроскопію. Згодом iï удосконалив у Полтавському технічному університеті наш колишній аспірант А.Т. Лобурець, завдяки чому стало можливим реєструвати панорамні знімки процесу дифузії, причому робити це 3 високою роздільною здатністю за відстанями і ступенем покриття.

Цей метод виявився дуже чутливим не лише до структури підкладки, а й до структурних перетворень у самій плівці. Наприклад, було виявлено суттєво різні механізми дифузії при різних взаємодіях на поверхні: один, що нагадує розстилання килима або гру в чехарду, і другий - «естафетний», або солітонний, що нагадує рух гусениці.

Так у нас розпочалася велика програма робіт у галузі двовимірної кристалографії і досліджень природи міжатомних взаємодій на поверхнях, адже саме вони і є тим фактором, знання якого дозволяє зрозуміти і потім практично використати безліч поверхневих явищ.

Підкладками в наших експериментах слугували грані кристалів тугоплавких металів вольфраму і молібдену (масивні), золота (у формі нанокристаликів), графіту і слюди. Адсорбатами були водень і кисень, метали (лужні, лужноземельні і рідкісноземельні) і органічні молекули ряду сполук. Ми досліджували роботу виходу електронів і енергію адсорбції, атомну структуру плівок, двовимірні фазові переходи в них і рухливість атомів (поверхневу дифузію), причому в максимально широких інтервалах температур. Експерименти з металами проводили в надвисокому вакуумі, а з органічними молекулами - в розчинах. Хімічну чистоту плівок контролювали методом ожеспектроскопії. Важливо також підкреслити, що визначали ми абсолютні концентрації адсорбованих атомів на поверхні, а не лише відносні ступені покриття. Також ми реалізували сканувальну тунельну мікроскопію в рідинах.
Усе це дозволило зібрати багатий експериментальний матеріал, який дав змогу глибше зрозуміти характер і механізми взаємодії атомів і молекул на поверхнях. Формування розріджених (тобто з великими міжатомними відстанями) структур відбувається при малих ступенях покриття лужними і лужноземельними металами ( $\mathrm{Li}, \mathrm{Na}, \mathrm{Cs}, \mathrm{Ba}$ та ін.). Це означає, що існує сильна відштовхувальна латеральна взаємодія електростатичної природи, коли зв'язок адатомів з підкладкою має полярний характер. Це переконливо підтвердили також наші спостереження дрейфу адатомів у неоднорідних електричних полях. На відміну від цього, на гранях 3 різко анізотропним (борознистим) рельєфом взаємодія адатомів виявилася також анізотропною. Крім того, наші експерименти підтвердили передбачення закордонних колег Т. Грімлі і Ж. Фріделя про існування далекосяжної «непрямої» латеральної обмінної взаємодії адатомів - через електронну систему підкладки. Ще одну можливість далекосяжної взаємодії на поверхнях передбачили В. Щукін і Д. Бімберг: у підкладці виникають пружні деформації внаслідок структурної неузгодженості між плівкою і підкладкою при епітаксії. Цей ефект аналогічний тому, що відбувається в об'ємі сплавів при мартенситних фазових перетвореннях. На поверхнях можливий також внесок у рушійну силу мезоскопічної (середньої між нано- і мікро-) самоорганізації від утворення ділянок з різною роботою виходу, як було передбачено Д. Вандербільтом. Для однієї з досліджуваних нами систем - Ce-O-Mo(112) нещодавно було виявлено структурну самоорганізацію з періодом, що сягає десятків нанометрів. Сьогодні навіть став популярним такий вислів: «Самоорганізація - це подарунок природи інженеру-нанотехнологу».

Окремий інтерес викликає адсорбція органічних молекул, які мають досить великий розмір і різноманітну форму. Осідаючи з розчинів, вони утворюють на поверхнях плетива дивовижної краси. Цю методику застосування сканувальної тунельної мікроскопії реалізував наш співробітник Олександр Анатолійович Марченко.

ISSN 1027-3239. Visn. Nac. Acad. Nauk Ukr. 2021. (6) 
Отже, сьогодні нам відомо про такі типи взаємодій на поверхнях, які можна використовувати для одержання поверхонь із заданими властивостями: пряма взаємодія - сильне обмінне (хімічне) притягання або дисоціація; пряма ван-дер-ваальсівська взаємодія (слабке притягання); пряма електростатична взаємодія (міждипольне відштовхування); непряма взаємодія через електронний газ підкладки (осцилююча); пряма взаємодія через електричне поле «плям» роботи виходу; непряма взаємодія через пружні деформації підкладки.

Що стосується практичних застосувань, то ми дали рекомендації з вибору поверхонь 3 підвищеною емісійною ефективністю, зокрема для термоемісійних перетворювачів теплової енергії в електричну, розроблених для використання в космічній техніці. Інші пропозиції стосуються каталізаторів, а також інженерії поверхонь з використанням органічних сполук.

Результати наших досліджень стали внеском у формування нового наукового напряму - двовимірної кристалографії. Їх узагальнено в монографії «Двумерные кристаллы» (И.Ф. Люксютов, А.Г. Наумовец, В.Л. Покровский), яка спочатку вийшла у видавництві
«Наукова думка», а потім, у перекладі англійською мовою, в США. Наші результати увійшли також до фундаментального підручника "Physics at Surfaces" (A. Zangwill, Cambridge, UK), який згодом було перевидано у Москві.

Зараз уже обгрунтовано твердження, що на поверхнях реалізуються агрегатні стани, подібні до відомих станів у трьох вимірах. Проте характер впорядкування деяких поверхневих структур усе ж має свою специфіку, яка визначається їх пониженою вимірністю. Міждисциплінарний напрям, про який я щойно розповідав, безумовно, має добрі перспективи на майбутнє. Крім традиційних галузей, слід відзначити важливість дослідження різноманітних біологічних поверхонь. Наприклад, використання стовбурових клітин має характерні ознаки епітаксійної технології.

На завершення хочу висловити глибоку вдячність усім, з ким я спільно отримував наведені тут результати, а також нашим вчителям і керівникам на чолі з незабутнім президентом нашої Академії Борисом Свгеновичем Патоном, які підтримували нашу роботу на всіх їі етапах. На жаль, багато з них уже пішли 3 життя.

Всім присутнім щиро дякую за увагу! 